\title{
Australian Journal of Crop Science \\ Growth and quality of Handroanthus impetiginosus (Mart. ex DC.) Mattos seedlings irrigated with saline fish effluent
}

\author{
Tiago de Sousa Leite ${ }^{1 *}$, Rômulo Magno Oliveira de Freitas ${ }^{2}$, Narjara Walessa Nogueira ${ }^{3}$, Hugo \\ Ferreira $^{3}$ and Moadir de Sousa Leite ${ }^{3}$
}

\author{
${ }^{1}$ Escola Superior de Agricultura "Luiz de Queiroz"/USP, Piracicaba, São Paulo, Brazil \\ ${ }^{2}$ Instituto Federal de Educação, Ciência e Tecnologia Baiano, Valença, Bahia, Brazil \\ ${ }^{3}$ Universidade Federal Rural do Semi-Árido, Mossoró, Rio Grande do Norte, Brazil
}

\section{*Corresponding author: tiagosousa@usp.br}

\begin{abstract}
Reusing wastewater for irrigation purposes is a sustainable approach for crop production in arid and semi-arid regions. Nevertheless, this technique requires further study on the response of plants to this type of water. This work aimed at assessing the growth and quality of Handroanthus impetiginosus (pink lapacho) seedlings irrigated with different concentrations of saline fish effluent. We used a randomized complete block design with four replicates and four plants per replicate. Treatments consisted of irrigation with five solutions containing different percentages of saline fish effluent diluted in tap water ( 0 [tap water], 25, 50, 75 and $100 \%$ fish effluent). At 60 days after transplanting, the effects of irrigation with saline fish effluent on the initial growth of seedlings were assessed based on shoot height, leaf number, stem diameter, shoot height/stem diameter ratio, leaf area, individual leaf area, leaf dry weight, stem dry weight, root dry weight, total dry weight, Dickson quality index, shoot height/shoot dry weight ratio and shoot dry weight/root dry weight ratio. The use of saline fish effluent diluted up to $50 \%$ of the irrigation water proved to be a feasible and sustainable practice for producing $H$. impetiginosus seedlings, with no negative effects on total dry weight and Dickson quality index. However, higher concentrations of this effluent caused a significant reduction in shoot height and leaf area.
\end{abstract}

Keywords: effluent management; forest tree seedlings; salt stress; water conservation; wastewater recycling.

\section{Introduction}

Handroanthus impetiginosus (Mart. ex DC.) Mattos, popularly known as pink lapacho, is a tree species of the Bignoniaceae family (Dombroski et al., 2014). Lima et al. (2014) mention the value of this tree for furniture manufacturing and to be used in programs aiming at the restoration of forest ecosystems. Wastewater recycling in agricultural systems consists in a sustainable approach for crop production in areas with low water availability. Through this practice, the use of drinkable water to irrigate crops in arid and semiarid regions could be minimized or even replaced worldwide (Rocha et al., 2014). In addition to supplying part of the plant water requirements, the reuse of wastewater can provide many of the nutrients necessary to plant growth, reducing the need for chemical fertilizers (Castro et al., 2005). According to Castro et al. (2005), wastewater recycling is associated with some benefits, such as water conservation, nutrient cycling and the reduction of environmental impacts due to improper disposal of nutrientrich waters into rivers and lakes. However, each type of wastewater has particular characteristics, which makes it necessary to understand the effects it could have on plant species when utilized in the irrigation process. Oliveira et al. (2009) explain that fish effluent can be considered a feasible water resource for irrigation due to a high concentration of plant nutrients, which results from the large amount of residues deposited at the bottom of fish ponds. On the other hand, the authors also elucidate that this effluent shows a high salt concentration, which causes an increase in electrical conductivity and generates a saline effect that could limit plant growth. To date, many researchers have studied the effects of salinity on the initial growth of tree species (Diniz Neto et al., 2014; Fernandes et al., 2003; Lima et al., 2015; Nunes et al., 2012; Silva et al., 2000; Silva et al., 2005; Sousa et al., 2011). Nevertheless, there have been few studies on the use of saline fish effluent for irrigation of forest tree seedlings. Yet, this research is important because of the high diversity in the tolerance of plant species to salt stress (Holanda et al., 2007). Despite the economic and ecological importance of $H$. impetiginosus, little is known about the techniques used for seedling production of this species. As far as we know, there has not been any study on the use of saline fish effluent for irrigation of $H$. impetiginosus seedlings. Considering all the benefits of wastewater recycling and given the lack of research on the reuse of saline fish effluent for production of forest tree seedlings, this study aimed at assessing the morphological response of $H$. impetiginosus seedlings to irrigation with different percentages of saline fish effluent diluted in the irrigation water.

\section{Results and Discussion}

Growth traits are modulated by irrigation with saline fish effluent

Irrigation with saline fish effluent during the initial growth of $H$. impetiginosus seedlings had a statistically significant effect on most plant traits, except for leaf number, stem 
Table 1. Physico-chemical properties of the five treatments utilized for irrigation.

\begin{tabular}{|c|c|c|c|c|c|c|c|c|c|c|c|}
\hline \multirow[b]{2}{*}{ Treatments } & \multirow[b]{2}{*}{$\mathrm{pH}$} & \multirow{2}{*}{ 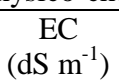 } & \multicolumn{3}{|c|}{ Anions $\left(\mathrm{mmol}_{\mathrm{s}} \mathrm{L}^{-1}\right)$} & \multicolumn{4}{|c|}{ Cations $\left(\mathrm{mmol}_{\mathrm{c}} \mathrm{L}^{-1}\right)$} & \multirow{2}{*}{$\begin{array}{c}\text { SAR* }^{*} \\
\left(\mathrm{mmol} \mathrm{L}^{-1}\right)^{0.5}\end{array}$} & \multirow[b]{2}{*}{ Class } \\
\hline & & & $\mathrm{CO}_{3}$ & $\mathrm{HCO}_{3}$ & $\mathrm{Cl}$ & $\mathrm{Mg}$ & $\mathrm{Ca}$ & $\mathrm{Na}^{2}$ & K & & \\
\hline $\mathrm{T} 1$ & 7.85 & 0.54 & 1.10 & 2.95 & 2.50 & 0.93 & 0.63 & 9.75 & 10.35 & 11.04 & $\mathrm{C} 2 \mathrm{~S} 2$ \\
\hline $\mathrm{T} 2$ & 8.25 & 1.56 & 1.20 & 2.80 & 8.90 & 3.59 & 3.31 & 22.50 & 15.55 & 12.11 & $\mathrm{C} 2 \mathrm{~S} 2$ \\
\hline $\mathrm{T} 3$ & 8.15 & 2.52 & 0.70 & 2.85 & 15.90 & 6.01 & 6.13 & 31.65 & 20.25 & 12.85 & $\mathrm{C} 4 \mathrm{~S} 2$ \\
\hline $\mathrm{T} 4$ & 8.15 & 3.44 & 1.00 & 3.55 & 22.20 & 10.30 & 8.55 & 42.90 & 28.30 & 13.97 & $\mathrm{C} 4 \mathrm{~S} 2$ \\
\hline T5 & 8.25 & 4.25 & 1.10 & 3.30 & 29.00 & 13.83 & 11.04 & 53.40 & 36.90 & 15.14 & $\mathrm{C} 4 \mathrm{~S} 2$ \\
\hline
\end{tabular}

$* \mathrm{SAR}=$ Sodium Adsorption Ratio. $\mathrm{SAR}=\mathrm{Na}^{+} /\left[\left(\mathrm{Ca}^{+2}+\mathrm{Mg}^{+2}\right) / 2\right]^{1 / 2}$
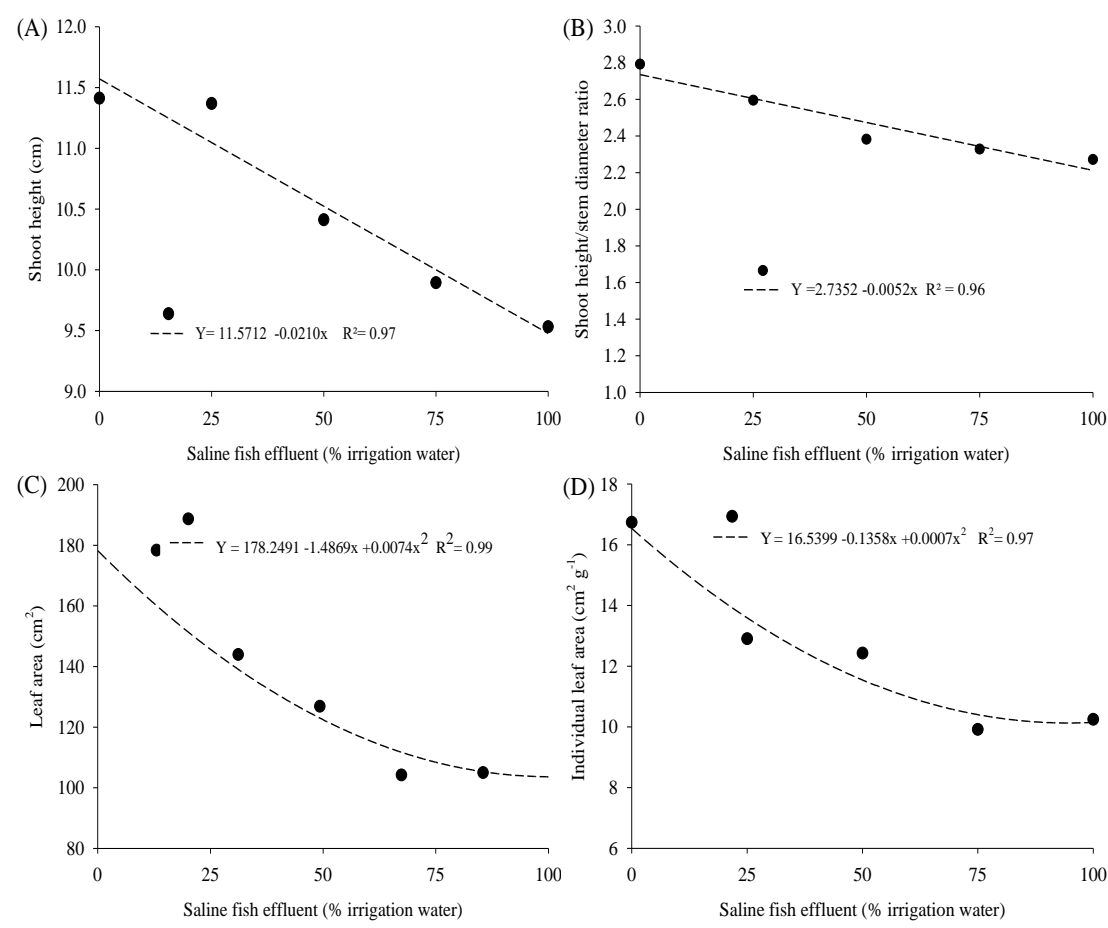

Fig 1. Growth traits are modulated by irrigation with saline fish effluent. (A) Shoot height, (B) shoot height/stem diameter ratio, (C) leaf area and (D) individual leaf area of $H$. impetiginosus seedlings irrigated with five percentages of saline fish effluent diluted in the irrigation water, at 60 days after transplanting.
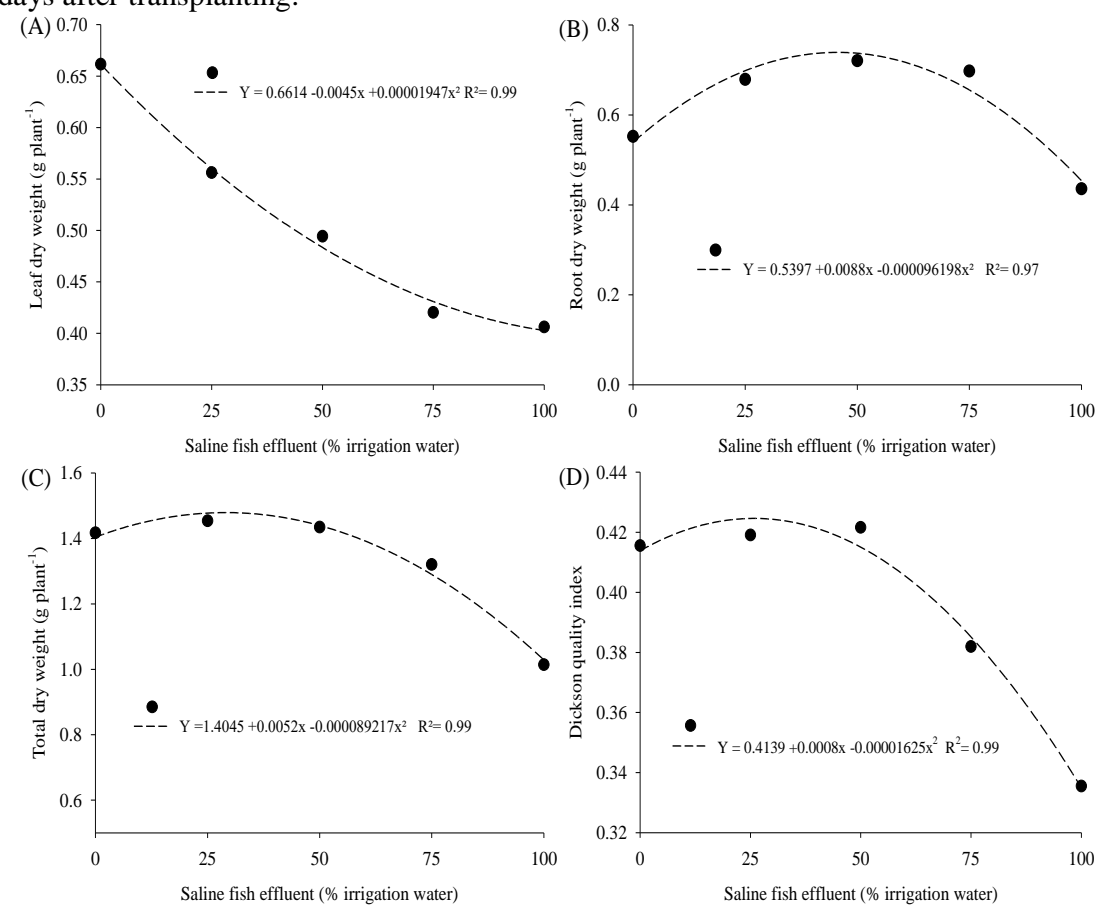

Fig 2. Irrigation with saline fish effluent alters biomass production and seedling quality. (A) Leaf dry weight, (B) root dry weight, (C) total dry weight and (D) Dickson quality index of $H$. impetiginosus seedlings irrigated with five percentages of saline fish effluent diluted in the irrigation water, at 60 days after transplanting. 

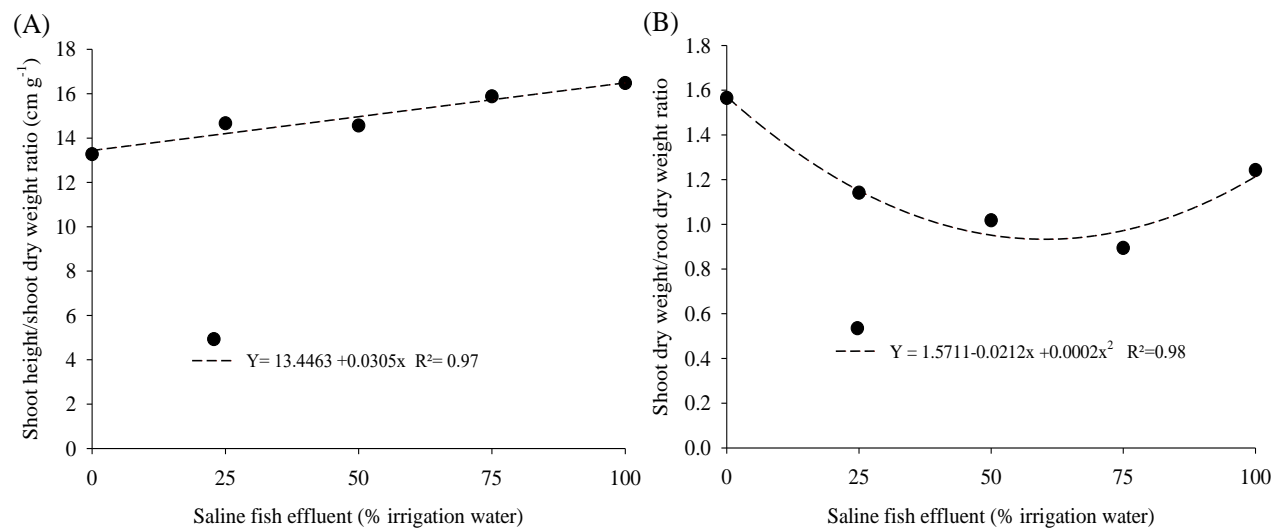

Fig 3. The percentage of saline fish effluent in the irrigation water determines quality indices. (A) Shoot height/shoot dry weight ratio and (B) shoot dry weight/root dry weight ratio of $H$. impetiginosus seedlings irrigated with five percentages of saline fish effluent diluted in the irrigation water, at 60 days after transplanting.

diameter and stem dry weight. Several studies have demonstrated negative effects of saline irrigation on shoot height (Diniz Neto et al., 2014; Oliveira et al., 2010; Sousa et al., 2011). In this study, shoot height was linearly affected by the dilution of saline fish effluent in the irrigation water (Fig 1A). However, differently from other tree species that are highly sensitive to salt stress (Fernandes et al., 2003; Lima et al., 2015), H. impetiginosus seedlings irrigated with $100 \%$ fish effluent were only $18 \%$ shorter than those irrigated exclusively with tap water (control).

Recent studies have suggested that the damages of saline irrigation to plants can be minimized if a nutrient source is readily available (Cavalcante et al., 2011; Nunes et al., 2012). Diniz Neto et al. (2014) were able to demonstrate that the effect of saline water on the initial growth of Licania rigida was reduced when plants were grown under organic fertilization. Taking into account the high concentration of plant nutrients in the fish effluent (Table 1), it is likely that the effect of salinity on shoot height of $\mathrm{H}$. impetiginosus seedlings was reduced.

Although the electrical conductivity (EC) of the fish effluent was nearly eightfold higher than that of tap water (Table 1), there was no statistical difference in stem diameter between control plants and those irrigated with $100 \%$ fish effluent. This means that the effect of salinity on stem growth is more significant for height than diameter. Consequently, shoot height/stem diameter ratio (Fig 1B) followed the same pattern as shoot height. Thus, for each increment of $25 \%$ in the concentration of saline fish effluent diluted in the irrigation water, shoot height/stem diameter ratio was reduced by approximately $4.75 \%$ in comparison to control plants.

Leaf area was negatively influenced by irrigation with saline fish effluent and showed a quadratic response (Fig 1C). Seedlings irrigated with solutions containing 25, 50, 75 and $100 \%$ fish effluent had their leaf area reduced by $18,31,39$ and $42 \%$, respectively, in relation to control plants. Depending on the irrigation method adopted, the leaves may be able to absorb salts directly from the water and accumulate them (Bernstein, 1975). As a result, leaf area turns out to be the most affected plant trait (Fernandes et al., 2003; Figueirêdo et al., 2006; Nery et al., 2009; Oliveira et al., 2010).

The total leaf area decreased proportionally to the reduction in individual leaf area (Fig 1D). According to Munns and Termaat (1986), leaves are more sensitive to salinity than other plant organs, such as roots. Furthermore, slow leaf growth is generally the first response of a non-halophyte plant subjected to salinity. Therefore, high concentrations of saline fish effluent should not be used to irrigate $H$. impetiginosus seedlings. Otherwise, the leaf area and total photosynthesis of this species might be significantly reduced (Chaves et al., 2009).

Irrigation with saline fish effluent alters biomass production and seedling quality

It is possible to notice a similarity between the curves expressing individual leaf area (Fig 1D) and leaf dry weight (Fig 2A). The decline in leaf size led to a decrease in total leaf dry weight, which is consistent with previous findings (Fernandes et al., 2003; Figueirêdo et al., 2006). Leaf dry weight was reduced by up to $39 \%$ when seedlings were irrigated exclusively with saline fish effluent. This consists in an adaptive response to salt stress, where plants tend to reduce their leaf area to minimize water loss through transpiration (Nery et al., 2009).

Differently from the leaves, roots actually benefited from the use of saline fish effluent (Fig 2B). Seedlings irrigated with $50 \%$ of this effluent had their root dry weight increased by approximately $37 \%$ in comparison to control plants. This might be due to a high concentration of plant nutrients in the fish effluent (Table 1) associated with a lower sensitivity of roots to salinity. The sensitivity to salinity differs among plant organs (Bernstein et al., 2010). The data of root dry weight corroborate the findings of Munns and Termaat (1986), who explain that root growth is generally less affected by salinity than shoot growth, or may even increase under salt stress.

The total dry weight of seedlings also benefited from the dilution of saline fish effluent up to about $50 \%$ of the irrigation water (Fig 2C). Previous research has shown an increase in total dry weight after irrigation with fish effluent (Castro et al., 2005; Rocha et al., 2014; Rodrigues et al., 2010). Nevertheless, in the conditions of this experiment, the total dry weight decreased nearly $8 \%$ in comparison to control plants when the concentration of fish effluent was elevated to $75 \%$.

The Dickson quality index is an integrated index that takes into account different plant traits to estimate seedling quality (Dickson et al., 1960). Although the EC of the solution containing $50 \%$ fish effluent was about fourfold higher than that of tap water (Table 1), there was no difference between the Dickson quality index of seedlings irrigated with 0 
(control) and 50\% saline fish effluent (Fig 2D). Essentially, these results suggest that the addition of this effluent at low concentrations in the irrigation water does not compromise the quality of $H$. impetiginosus seedlings.

\section{The percentage of saline fish effluent in the irrigation water determines quality indices}

Although shoot height decreased proportionally to the dilution of fish effluent in the irrigation water, the shoot height/shoot dry weight ratio slightly increase (Fig 3A). Thus, it can be concluded that shoot dry weight decreased at a faster rate, being considerably more affected by salinity. The shoot height/shoot dry weight ratio of seedlings irrigated with $25,50,75$ and $100 \%$ fish effluent were $6,11,17$ and $23 \%$, respectively, higher than that found in control plants. Because shoot growth is more sensitive to salinity than root growth (Munns and Termaat, 1986), the shoot dry weight/root dry weight ratio is expected to decrease under salt stress conditions. However, this will not necessarily occur in a linear manner, given that high salinity levels may also reduce root growth (Diniz Neto et al., 2014). It is possible to observe a quadratic effect on the shoot dry weight/root dry weight ratio (Fig 3B), which had a value close to 1.0 when plants were irrigated with $50 \%$ saline fish effluent.

\section{Materials and Methods}

\section{Study area and experimental design}

The study was conducted from June to August 2013 at the Universidade Federal Rural do Semi-Árido (UFERSA), in Mossoró $\left(05^{\circ} 11^{\prime} \mathrm{S}, 37^{\circ} 20^{\prime} \mathrm{W}, 18 \mathrm{~m}\right)$, Rio Grande do Norte, Brazil. The region is characterized by a hot and dry climate, with a mean annual temperature of $27.5^{\circ} \mathrm{C}$, relative humidity of $68.9 \%$ and rainfall of $673.9 \mathrm{~mm}$ (Carmo Filho et al., 1991). During the experiment, in a seedling nursery with $50 \%$ shade, we verified a mean temperature of $28.5^{\circ} \mathrm{C}$ and relative humidity of $68.3 \%$.

Treatments were laid out in a randomized complete block design, with four replicates and four plants per replicate, and consisted of irrigation with five solutions containing different percentages of saline fish effluent diluted in tap water ( 0 [tap water], 25, 50, 75 and 100\% fish effluent). Fish effluent from an intensive tilapia culture system was provided by the aquaculture sector of the Department of Animal Science of UFERSA. Physical and chemical properties of the five solutions (treatments) are present in Table 1.

\section{Plant and soil material}

The seeds used in this study were collected from 20 trees in a nearby area. They were selected and sown in polystyrene trays containing coconut fibre. At 21 days after sowing, when seedlings had two pairs of fully expanded leaves, they were transplanted into $0.9 \mathrm{~L}$ polyethylene plastic bags filled with topsoil. After transplanting, each plot was irrigated daily with $200 \mathrm{~mL}$ of water or saline solution, according to the treatments (Table 1).

Textural and chemical analyses of the topsoil used showed the following results: coarse sand $-0.66 \mathrm{~kg} \mathrm{~kg}^{-1}$; fine sand $0.21 \mathrm{~kg} \mathrm{~kg}^{-1}$; total sand $-0.87 \mathrm{~kg} \mathrm{~kg}^{-1}$; silt $-0.09 \mathrm{~kg} \mathrm{~kg}^{-1}$; clay - $0.04 \mathrm{~kg} \mathrm{~kg}^{-1}$; $\mathrm{pH}$ in $\mathrm{H}_{2} \mathrm{O}-8.28$; EC $-0.13 \mathrm{dS} \mathrm{m}^{-1}$; organic matter - $11.36 \mathrm{~g} \mathrm{~kg}^{-1} ; \mathrm{N}-0.35 \mathrm{~g} \mathrm{~kg}^{-1} ; \mathrm{P}-25.8 \mathrm{mg} \mathrm{dm}{ }^{-3} ; \mathrm{K}^{+}$$98.85 \mathrm{mg} \mathrm{dm}{ }^{-3} ; \mathrm{Na}^{+}-95 \mathrm{mg} \mathrm{dm}{ }^{-3} ; \mathrm{Ca}^{2+}-3.2 \mathrm{cmol}_{\mathrm{c}} \mathrm{dm}^{-3}$;
$\mathrm{Mg}^{2+}-0.48 \mathrm{cmol}_{\mathrm{c}} \mathrm{dm}^{-3} ; \mathrm{Cu}-0.06 \mathrm{mg} \mathrm{dm}^{-3} ; \mathrm{Fe}-2.2 \mathrm{mg} \mathrm{dm}^{-3} ;$ $\mathrm{Mn}-11.3 \mathrm{mg} \mathrm{dm}^{-3}$; and $\mathrm{Zn}-3.63 \mathrm{mg} \mathrm{dm}^{-3}$.

\section{Assessment of seedling growth and quality}

At 60 days after transplanting, the effects of irrigation with saline fish effluent on the initial growth of seedlings were assessed by the following parameters: shoot height, leaf number, stem diameter, shoot height/stem diameter ratio, leaf area, individual leaf area, leaf dry weight, stem dry weight, root dry weight, total dry weight, shoot height/shoot dry weight ratio and shoot dry weight/root dry weight ratio. In addition, seedling quality was estimated using the Dickson quality index (Dickson et al., 1960).

Leaf area was assessed as proposed by Souza et al. (2012). Thus, we determined the dry weight of ten $1.72-\mathrm{cm}^{2}$ discs, which were randomly collected from leaves of each replicate. The leaf area of each seedling was then estimated based on the area and dry weight of the discs and the total leaf dry weight. Individual leaf area was calculated by the ratio of leaf area to the number of leaves. For dry weight assessment, two plants per replicate were divided into leaves, stems and roots and placed in a dry oven at $65^{\circ} \mathrm{C}$ for three days.

\section{Statistical analysis}

Data were analysed by one-way ANOVA using the Sisvar statistical analysis software (Ferreira, 2011). Statistically significant results (F-test, $p<0.05$ ) were also subjected to regression analysis using the SigmaPlot graphing software (version 11.0; Systat Software, Inc.).

\section{Conclusion}

There were no negative effects on the total dry weight and Dickson quality index of $H$. impetiginosus seedlings irrigated with up to $50 \%$ saline fish effluent. However, higher concentrations of this effluent caused a significant reduction in shoot height and leaf area. The use of saline fish effluent diluted up to $50 \%$ of the irrigation water proved to be a feasible and sustainable practice for producing $H$. impetiginosus seedlings.

\section{Acknowledgements}

We gratefully acknowledge the Universidade Federal Rural do Semi-Árido for financially supporting this research.

\section{References}

Bernstein L (1975) Effects of salinity and sodicity on plant growth. Annu Rev Phytopathol. 13:295-312.

Bernstein N, Shoresh M, Xu Y, Huang B (2010) Involvement of the plant antioxidative response in the differential growth sensitivity to salinity of leaves vs roots during cell development. Free Radic Biol Med. 49:1161-1171.

Carmo Filho F, Espínola Sobrinho J, Maia Neto JM (1991) Dados climatológicos de Mossoró: um município semiárido nordestino. $1^{\text {st }}$ edn. ESAM, Mossoró. $121 \mathrm{p}$.

Castro RS, Azevedo CMSB, Barbosa MR (2005) Efeitos de efluente de viveiro de piscicultura e de água de poço na irrigação do tomate cereja, cultivado em diferentes níveis de adubação orgânica. Cienc Agron. 36:396-399.

Cavalcante LF, Rebequi AM, Sena GSA, Nunes JC (2011) Irrigação com águas salinas e uso de biofertilizante bovino na formação de mudas de pinhão-manso. Irriga. 16:288300 
Chaves MM, Flexas J, Pinheiro C (2009) Photosynthesis under drought and salt stress: regulation mechanisms from whole plant to cell. Ann Bot. 103:551-560.

Dickson A, Leaf AL, Hosner JF (1960) Quality appraisal of white spruce and white pine seedling stock in nurseries. For Chron. 36:10-13.

Diniz Neto MA, Silva IF, Cavalcante LF, Diniz BLMT, Silva JCA, Silva EC (2014) Mudas de oiticica irrigadas com águas salinas no solo com biofertilizante bovino e potássio. Rev Bras Eng Agric Ambient. 18:10-18.

Dombroski JLD, Freitas RMO, Tomczak VE, Pinto JRS, Farias RM (2014) Ecophysiology of water stressed Handroanthus impetiginosus (Mart. Ex. DC) Mattos seedlings. Sci For. 42:155-163.

Fernandes AR, Carvalho JG, Curi N, Guimarães PTG, Pinto JEBP (2003) Crescimento de mudas de pupunheira (Bactris gasipaes H.B.K.) sob diferentes níveis de salinidade. Cienc Agrotecnol. 27:278-284.

Ferreira DF (2011) Sisvar: a computer statistical analysis system. Cienc Agrotecnol. 35:1039-1042.

Figueirêdo VB, Faria MA, Silva EL (2006) Crescimento inicial do cafeeiro irrigado com água salina e salinização do solo. Rev Bras Eng Agric Ambient. 10:50-57.

Holanda AC, Santos RV, Souto JS, Alves AR (2007) Desenvolvimento inicial de espécies arbóreas em ambientes degradados por sais. Rev Biol Cienc Terra. 7:39-50.

Lima MFP, Porto MAF, Torres SB, Freitas RMO, Nogueira NW, Carvalho DR (2015) Emergência e crescimento inicial de plântulas de albízia submetidas à irrigação com água salina. Rev Bras Eng Agric Ambient. 19:106-112.

Lima PR, Horbach MA, Dranski JAL, Ecco M, Malavasi MM, Malavasi UC (2014) Avaliação morfofisiológica em mudas de Handroanthus impetiginosus (Mart. ex DC.) Mattos durante a rustificação. Flor Ambient. 21:316-326.

Munns R, Termaat A (1986) Whole-plant responses to salinity. Aust J Plant Physiol. 13:143-160.

Nery AR, Rodrigues LN, Silva MBR, Fernandes PD, Chaves LHG, Dantas Neto J, Gheyi HR (2009) Crescimento do pinhão-manso irrigado com águas salinas em ambiente protegido. Rev Bras Eng Agric Ambient. 13:551-558.

Nunes JC, Cavalcante LF, Lima Neto AJ, Rebequi AM, Diniz BLMT, Gheyi HR (2012) Comportamento de mudas de nim à salinidade da água em solo não salino com biofertilizante. Rev Bras Eng Agric Ambient. 16:11521158.

Oliveira HV, Bezerra Neto F, Azevedo CMSB, Lima CB, Gurgel GCS (2009) Alterações nas características químicas de um Argissolo Vermelho-Amarelo irrigado com efluente de piscicultura, em ambiente protegido. Rev Agroambient Online. 3:9-14.

Oliveira IRS, Oliveira FN, Medeiros MA, Torres SB, Teixeira FJV (2010) Crescimento inicial do pinhão-manso (Jatropha curcas L.) em função da salinidade da água de irrigação. Rev Caatinga. 23:40-45.

Rocha SA, Garcia GO, Lougon MS, Cecílio RA, Caldeira MVW (2014) Crescimento e nutrição foliar de mudas de Eucalyptus sp. irrigadas com diferentes qualidades de água. Rev Cienc Agrar. 37:141-151.
Rodrigues DS, Leonardo AFG, Nomura ES, Tachibana L, Garcia VA, Correa CF (2010) Produção de mudas de tomateiro em sistemas flutuantes com adubos químicos e água residuária de viveiros de piscicultura. Rev Bras Cienc Agrar. 5:32-35.

Silva FAM, Melloni R, Miranda JRP, Carvalho JG (2000) Efeito do estresse salino sobre a nutrição mineral e o crescimento de mudas de aroeira (Myracrodruon urundeuva) cultivadas em solução nutritiva. Cerne. 6:5259.

Silva MBR, Batista RC, Lima VLA, Barbosa EM, Barbosa MFN (2005) Crescimento de plantas jovens da espécie florestal favela (Cnidosculus phyllacanthus Pax \& K. Hoffm) em diferentes níveis de salinidade da água. Rev Biol Cienc Terra. 5:1-13.

Sousa ABO, Bezerra MA, Farias FC (2011) Germinação e desenvolvimento inicial de clones de cajueiro comum sob irrigação com água salina. Rev Bras Eng Agric Ambient. 15:390-394.

Souza MS, Alves SSV, Dombroski JLD, Freitas JDB, Aroucha EMM (2012) Comparação de métodos de mensuração de área foliar para a cultura da melancia. Pesqui Agropecu Trop. 42:241-245. 